\title{
Communication
}

[Comunicação]

\section{Parasitism of a capybara (Hydrochoerus hydrochaeris) by Amblyomma nodosum Neumann, 1899 and Amblyomma humerale Koch, 1844 in an Amazon forest area, Rondônia, Brazil}

\author{
[Parasitismo por Amblyomma nodosum Neumann, 1899 e Amblyomma humerale Koch, 1844 \\ em capivara (Hydrochoerus hydrochaeris) em área de Floresta Amazônica, Rondônia, Brasil] \\ R.B.N. Fuverki ${ }^{1,4}$, A.L. Martins ${ }^{1}$, T.F. Martins ${ }^{2}$, L.S. Muraro ${ }^{3}$, A.O. Souza ${ }^{4}$, \\ J.L. Barbosa ${ }^{1}$, A.P. Almeida ${ }^{1}$, D.M. Aguiar ${ }^{4}$ \\ ${ }^{1}$ Centro Universitário São Lucas Ji-Paraná - Ji-Paraná, RO \\ ${ }^{2}$ Faculdade de Medicina Veterinária e Zootecnia - Universidade de São Paulo - São Paulo, SP \\ ${ }^{3}$ Universidade de Cuiabá - Cuiabá, MT \\ ${ }^{4}$ Laboratório de Virologia e Rickettsioses - Universidade Federal de Mato Grosso - Cuiabá, MT
}

Tick fauna in Brazil are estimated to comprise 70 species, mostly of the genus Amblyomma (DantasTorres et al., 2019). Among them, Amblyomma nodosum is known as a Neotropical tick already reported in several states in Brazil, probably because its hosts occur in all Brazilian biomes (Mazioli et al., 2012). The species parasitized by A. nodosum ticks include anteaters, wild birds and domestic dogs, and the most numerous reports involve anteaters (Mazioli et al., 2012). This can be explained by the fact that anteaters are the natural host of $A$. nodosum in the adult stage, while a variety of birds are hosts of its immature stages (Barros-Battesti et al., 2006). A. nodosum has been found to be highly dependent on its hosts and environment (Pinheiro et al., 2015).

Amblyomma humerale, another important species of the genus Amblyomma, is considered endemic to South America, where it has been mainly described parasitizing land tortoises, including reports in Rondônia (Labruna et al., 2002). Its parasitism on a lizard has also been described by Zimmermann et al. (2018) in the same state. In addition to the veterinary importance of ticks as animal parasites, several reports have shown the detection of microorganisms in A. nodosum and $A$. humerale such as Rickettsiae, what could eventually be related to human health risks (Labruna et al., 2004; Ogrzewalska et al., 2009; Almeida et al., 2013; Soares et al., 2015; Witter et al., 2016; Machado et al, 2018; Moerbeck et al., 2018). This justifies the interest in conducting research on these ectoparasites in areas rich in biodiversity, especially the Amazon region.

In November 2019 adult ticks were found attached to a capybara, which was sent for veterinary treatment in the municipality of $\mathrm{Ji}$ Paraná $\left(10^{\circ} 53^{\prime} \mathrm{S}, 61^{\circ} 57^{\prime} \mathrm{W}\right)$, in the state of Rondônia, northern Brazil. Located in the center of the state on the banks of the Machado river, this municipality has a population of 128,969 (Cidades..., 2019) and capybaras are commonly sighted in its forests, along roadsides and in the municipality's peri-urban areas such as public parks.

A female capybara weighing approximately $45 \mathrm{~kg}$ was found injured in a rural area by environmental police and taken to a university veterinary hospital, where a clinical examination found it was already dead. During the physical examination of the animal, two ticks were noted on the animal's back. These ticks were removed by hand or with anatomical forceps in order to preserve their structures. They were stored in $70 \%$ ethanol and sent to the laboratory for taxonomic identification of adult ticks, as proposed by Barros-Battesti et al. (2006). Two engorged female ticks were morphologically identified as $A$. nodosum and $A$. humerale (Figure 1). No male

Recebido em 30 de junho de 2020

Aceito em 5 de novembro de 2020

E-mail: renatafuverki@gmail.com 
ticks were found despite these engorged females, probably because at the time of the collection the animal was already dead, and they may have left the carcass due to its cooling.

The A. nodosum tick was characterized by a well ornamented and symmetrically arranged scutum, with pale Y-shaped anterolateral smudges and an irregular posterior smudge. Palpal segment II was found to be twice as large as palpal segment III and its dorsal surface presented an oblique crest. The festoons were devoid of chitinous tubercles. Coxa I had two spurs, which were shorter than the coxa, and the internal one was not vestigial. Coxa IV had one straight spur and the trochanters lacked spurs. The hypostome dentition was $3 / 3$ with a rounded apex. This description is in line with that presented by Barros-Battesti et al. (2006) for A. nodosum.

The A. humerale tick presented hypostome dentition 4/4, glabrous alloscutum and spiracular plates lacking festooned margins. The scutum had two bright, symmetrically arranged stripes in the scapular fields. The festoons lacked chitinous tubercles and coxa IV had two conspicuous spurs, which is congruent with the morphology of $A$. humerale described by Barros-Battesti et al. (2006).
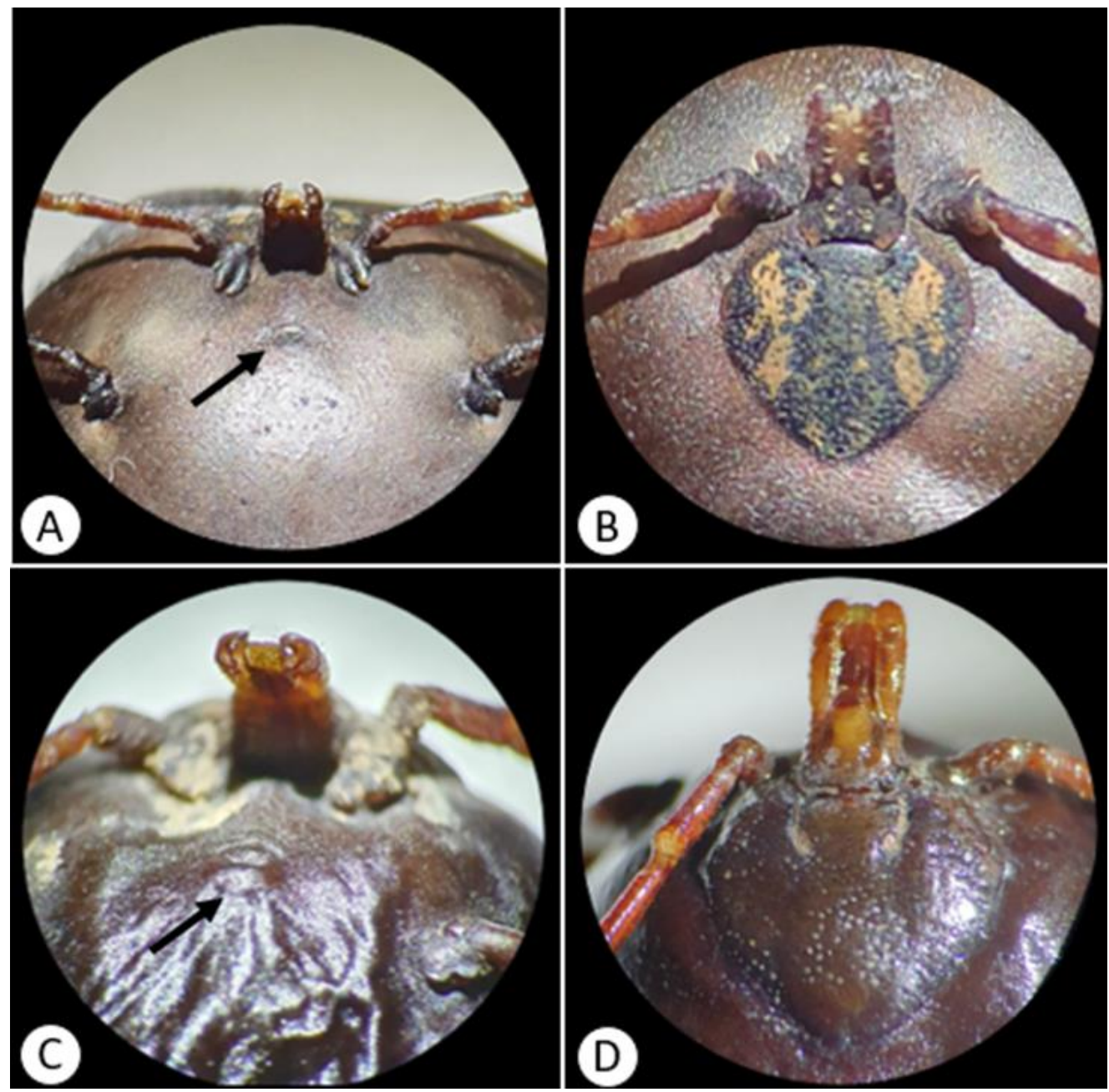

Figure 1. Ticks collected from a capybara (Hydrochoerus hydrochaeris) in the region of the municipality of Ji-Paraná, Rondônia, Western Amazon. A: Amblyomma nodosum, female, ventral, with visible genital aperture (50x magnification). B: Amblyomma nodosum, female, scutum ornamentation pattern (50x magnification). C: Amblyomma humerale, female, ventral, with visible genital aperture (50x magnification). D: Amblyomma humerale, female, scutum ornamentation pattern (50x magnification). 
No reports were found of A. humerale on capybaras in Rondônia. In this region, the animal species found to be parasitized by this tick were reptiles such as tortoises (Chelonoidis denticulatus, and Chelonoidis carbonaria), common caimans (Caiman crocodilus) and lizards (Plica plica, Plica umbra, Kentropyx calcarata and Uranoscodon superciliosus) (Labruna et al., 2002, 2005; Zimmermann et al., 2018). In this state, armadillos, silky anteaters (Cyclopes didactylus) and common opossums (Didelphis marsupialis) were the only mammal species found to be parasitized by A. humerale, albeit in its nymph stage (Labruna et al., 2005; Martins et al., 2014). The presence of free-living A. humerale on vegetation was also described by Labruna et al. (2004) in Rondônia, in the region of the Jamari River, where animals also tested positive for Rickettsia bellii. This location is about 160 kilometers away from the region of the present study.

Parasitism of free-living capybaras by $A$. humerale has already been reported by Gruhn et al. (2019) in the state of Acre, in the Western Amazon, although its parasitism rate was low compared to that of other Amblyomma species that were also found. However, these ticks were in their nymph stages, unlike those in our study, which involved the adult and engorged stages of this parasite. No other reports of A. humerale parasitism on capybaras were found in the literature consulted.

There are several reports of the tick A. nodosum in Brazil, parasitizing mainly anteaters in various regions of the country, including the states of Mato Grosso, Goiás, Ceará (Witter et al., 2016; Machado et al, 2018; Moerbeck et al., 2018), Mato Grosso do Sul (Garcia et al., 2013) and Rondônia (Zimmermann et al., 2018). The occurrence of A. nodosum in Rondônia has been reported since 2005, where these ticks were found by Labruna et al. (2005) and Martins et al. (2014) on anteaters in different municipalities.

Likewise, reports of this species on birds are distributed throughout Brazil, including the states of Minas Gerais (Zeringota et al., 2017), Mato Grosso do Sul and Mato Grosso (Garcia et al., 2013; Witter et al., 2016), as well as in the northeast region (Lugarini et al., 2015). The presence of $A$. nodosum on domestic dogs has been reported on two occasions in Brazil. Sabatini et al. (2010) reported finding adult $A$. nodosum ticks on two dogs in the state of São Paulo, and Mazioli et al. (2012) reported an adult tick attached to a domestic dog in the state of Espírito Santo. Both studies considered these findings incidental. However, we found no reports of $A$. nodosum parasitizing capybaras in Rondônia, in Brazil or in another location in the neotropical region.

This study contributes by describing the distribution of Amblyomma ticks in the western Amazon region, and by adding to the list of hosts of A. nodosum and A. humerale since, to the best of our knowledge, this is the first report of the occurrence of an adult $A$. nodosum and an adult $A$. humerale parasitizing a capybara $(H$. hydrochaeris). Our results suggest that these ticks cannot withstand the various studies that have focused on tick populations in Rondônia (Labruna et al., 2005, 2010; Martins et al., 2014; Zimmermann et al., 2018), information is still scarce and more research into the hosts and ecology of both ticks is needed, since they have been linked to infectious agents that are potentially pathogenic for humans, such as Rickettsia spp. (Soares et al., 2015; Witter et al., 2016; Moerbeck et al., 2018).

\section{ACKNOWLEDGEMENTS}

We gratefully acknowledge the financial support of the Brazilian research funding agencies FAPERO (State of Rondônia Foundation for the Support of Scientific and Technological Development and Research) and CNPq (National Council for Scientific and Technological Development). We also acknowledge $\mathrm{CNPq}$ for the research productivity grant awarded to D.M. Aguiar, as well as FAPESP (São Paulo Research Foundation) for the research grant awarded to T.F. Martins, and MEC (Ministry of Education) for scholarships granted to A.O. Souza. DM Aguiar thanks God for his life and for his work in veterinary medicine.

Keywords: new host, Amblyomma, capybara, Acari, Ixodidae 


\section{RESUMO}

Dois carrapatos adultos, sendo um Amblyomma nodosum e um Amblyomma humerale foram encontrados parasitando ativamente uma capivara (Hydrochoerus hydrochaeris) proveniente da região central do estado de Rondônia, Brasil, na zona rural do município de Ji-Paraná, localizado na Amazônia ocidental. Poucos trabalhos científicos relatam a presença de A. humerale em capivaras. Assim, esta é a primeira vez que A. nodosum é relatado parasitando essa espécie animal. Por não se tratar de um hospedeiro animal conhecido para A. nodosum ou comum para A. humerale, esses achados podem sugerir uma nova relação entre hospedeiros para eles. Portanto, são necessários mais estudos acerca da ecologia desses parasitas, principalmente por serem potenciais transmissores de patógenos de importância em medicina veterinária e saúde pública.

Palavras-chave: novo hospedeiro, Amblyomma, capivara, Acari, Ixodidae

\section{REFERENCES}

ALMEIDA, R.F.; GARCIA, M.V.; CUNHA, R.C. et al. The first report of Rickettsia spp. in Amblyomma nodosum in the State of Mato Grosso do Sul, Brazil. Ticks Tick Borne Dis., v.4, p.156159,2013

BARROS-BATTESTI, D.M.; ARZUA, M.; BECHARA, G.H. Carrapatos de importância médico-veterinária da região neotropical: um guia ilustrado para identificação de espécies. São Paulo: Vox/ICTTD-3/Butantan, 2006.

DANTAS-TORRES, F.; MARTINS, T.F.; MUÑOZ-LEAL, S.; ONOFRIO, V.C.; BARROSBATTESTI, D.M. Ticks (Ixodida: Argasidae, Ixodidae) of Brazil: Updated species checklist and taxonomic keys. Ticks Tick Borne Dis., v.10, p.101252, 2019.

GARCIA, M.V.; SILVA, D.C.; ALMEIDA, R.F. et al. Environmentally associated ticks (Acari: Ixodidae) in Campo Grande, Mato Grosso do Sul, Brazil. Rev. Bras. Parasitol. Vet., v.22, p.124128, 2013.

GRUHN, K.D.; OGRZEWALSKA, M.; ROZENTAL, T. et al. Evaluation of rickettsial infection in free-range capybaras (Hydrochoerus hydrochaeris Linnaeus, 1766) (Rodentia: Caviidae) and ticks (Acari: Ixodidae) in the Western Amazon, Brazil. Ticks Tick Borne Dis., v.10, p.981-986, 2019.

LABRUNA, M.B.; BARBIERI, F.S.; MARTINS, T.F.; BRITO, L.G.; RIBEIRO, F.D.S. New tick records in Rondônia, Western Brazilian Amazon. Rev. Bras. Parasitol. Vet., v.19, p.192-194, 2010.
LABRUNA, M.B.; CAMARGO, L.M.A.; TERASSINI, F.A. et al. Ticks (Acari: Ixodidae) from the state of Rondônia, western Amazon, Brazil. Syst. Appl. Acarol., v.10, p.17-32, 2005.

LABRUNA, M.B.; CAMARGO, L.M.A.; TERRASSINI, F.A.; SCHUMAKER, T.T.S.; CAMARGO, E.P. Notes on parasitism by Amblyomma humerale (Acari: Ixodidae) in the State of Rondônia, Western Amazon, Brazil. J. Med. Entomol., v.39, p.814-817, 2002.

LABRUNA, M.B.; WHITWORTH, T.; BOUYER, D.H. et al. Rickettsia bellii and Rickettsia amblyommii in Amblyomma ticks from the State of Rondônia, Western Amazon, Brazil. J. Med. Entomol., v.41, p.1073-1081, 2004.

LUGARINI, C.; MARTINS, T.F.; OGRZEWALSKA, M. et al. Rickettsial agents in avian ixodid ticks in northeast Brazil. Ticks Tick Borne Dis., v.6, p.364-375, 2015.

MACHADO, I.B.; BITTENCOURTH, K.; CARDOSO, K.M. et al. Diversity of Rickettsiae and potential vectors of spotted fever in an area of epidemiological interest in the Cerrado biome, midwestern Brazil. Med. Vet. Entomol., v.32, p.481-489, 2018.

MARTINS, T.F.; VENZAL, J.M.; TERASSINI, F.A. et al. New tick records from the state of Rondônia, western Amazon, Brazil. Exp. Appl. Acarol., v.62, p.121-128, 2014.

MAZIOLI, R.; SZABÓ, M.; MAFRA, C. Amblyommanodosum (Acari: Ixodidae) parasitizing a domestic dog in Colatina, Espírito Santo, Brazil. Rev. Bras. Parasitol. Vet., v.21, p.428-432, 2012. 
MOERBECK, L.; VIZZONI, V.F.; OLIVEIRA, S.V. et al. Rickettsia sp. Strain NOD infecting ticks (Amblyomma nodosum) in an endemic area of Spotted Fever in Brazil. J. Wildl. Dis., v.54, p.406-409, 2018.

OGRZEWALSKA, M.; PACHECO, R.C.; UEZU, A. et al._Rickettsial infection in Amblyomma nodosum ticks (Acari:Ixodidae) from Brazil. Ann. Trop. Med. Parasitol., v.103, p.413-425, 2009.

PINHEIRO, M.C.; LOURENÇO, E.C.; SÁHÚNGARO, I.J.; FAMADAS, K.M. Amblyomma nodosum (Neumann, 1899): observations on life cycle under laboratory conditions. Rev. Bras. Parasitol. Vet., v.24, p.357-360, 2015.

SABATINI, G.S.; PINTER, A.; NIERI-BASTOS, F.A.; MARCILI, A.; LABRUNA, M.B. Survey of ticks (Acari: Ixodidae) and their Rickettsia in an Atlantic rain forest reserve in the state of São Paulo, Brazil. J. Med. Entomol., v.47, p.913-916, 2010.

SOARES, H.S.; BARBIERI, A.R.M.; MARTINS, T.F. et al. Ticks and rickettsial infection in the wildlife of two regions of the Brazilian Amazon. Exp. Appl. Acarol., v.65, p.125-140.
CIDADES e estados. Rio de Janeiro: IBGE, 2019 Available in:

http://www.ibge.gov.br/cidadesat/painel/painel.p hp?codmun=320150\#. Accessed in: 8 Mar. 2020.

WITTER, R.; MARTINS, T.F.; CAMPOS, A.K.; MELO, A.L.T.; CORRÊA, S.H.R.; MORGADO, T.O. Rickettsial infection in ticks (Acari: Ixodidae) of wild animals in midwestern Brazil. Ticks Tick Borne Dis., v.7, p.415-423, 2016.

ZERINGÓTA, V.; MATURANO, R.; LUZ, H.R.; SENRA, T.O.S.; DAEMON, E.; FACCINI, J.L.H. Molecular detection of Rickettsia rhipicephali and other spotted fever group Rickettsia species in Amblyomma ticks infesting wild birds in the state of Minas Gerais, Brazil. Ticks Tick Borne Dis., v.8, p.81-89, 2017.

ZIMMERMANN, N.P.; AGUIRRE, A.A.R.; RODRIGUES, V.S. et al. Wildlife species, Ixodid fauna and new host records for ticks in an Amazon forest area, Rondônia, Brazil. Rev. Bras. Parasitol. Vet., v.27, p.177-182, 2018. 